\title{
Keterlibatan Orang Tua di Minangkabau dalam PAUD pada Masa Pandemi Covid-19
}

\author{
Regina Azzahra ${ }^{\circledR}{ }^{\bowtie}$,Wahidah Fitriani ${ }^{1}$, Desmita ${ }^{1}$, Jhoni Warmansyah ${ }^{1}$ \\ Pendidikan Islam Anak Usia Dini, Institut Agama Islam Negeri Batusangkar, Indonesia(1) \\ DOI: $\underline{10.31004 / \text { obsesi.v6i3.1796 }}$
}

\begin{abstract}
Abstrak
Kesibukan orang tua dalam bekerja membuat orang tua tidak dapat sepenuhnya ikut serta dalam pendidikan dan kegiatan anak mereka. Dengan adanya pandemi covid-19 orang tua mengatakan bahwa mereka sulit melibatkan diri dalam pendidikan anak dikarenakan ekonomi keluarga yang menurun. Tujuan penelitian ini adalah untuk mendeskripsikan keterlibatan orang tua di Minangkabau dalam pendidikan anak usia dini pada masa pandemi covid-19. Jenis penelitian ini ialah deskriptif kualitatif. Pengambilan data bersumber dari data primer dan data sekunder. Pengumpulan data menggunakan teknik triangulasi yaitu dengan wawancara, observasi dan dokumentasi. Hasil penelitian ini menunjukkan bahwa keterlibatan orang tua di Minangkabau dalam pendidikan anak usia dini pada masa pandemi covid-19 terbilang masih ada namun memang tidak sepenuhnya dilakukan oleh orang tua dikarenakan kesibukan dalam bekerja serta berdagang. Terlibatnya orang tua dalam pendidikan anak dapat bermanfaat bagi anak dengan perkembangan kemampuan anak yang meningkat, pihak sekolah merasa puas dengan sudah terlaksananya seluruh program sekolah yang sudah direncanakan dan orang tua sendiri dapat menambah semangatnya untuk meningkatkan pendidikan anak.
\end{abstract}

Kata Kunci: anak usia dini; keterlibatan orang tua; paud.

\begin{abstract}
The busyness of parents in working makes parents unable to fully participate in the education and activities of their children. With the COVID-19 pandemic, parents said that it was difficult for them to involve themselves in their children's education due to the declining family economy. The purpose of this study was to describe the involvement of parents in Minangkabau in early childhood education during the COVID-19 pandemic. This type of research is descriptive qualitative. Data retrieval sourced from primary data and secondary data. Collecting data using triangulation techniques, namely interviews, observation and documentation. The results of this study indicate that the involvement of parents in Minangkabau in early childhood education during the COVID-19 pandemic is still present but it is not fully carried out by parents due to busy work and trading. The involvement of parents in children's education can be beneficial for children with the development of children's increased abilities, the school is satisfied with the implementation of all planned school programs and parents themselves can increase their enthusiasm to improve children's education.
\end{abstract}

Keywords: Early Childhood, Parental Involvement, PAUD.

Copyright (c) 2021 Regina Azzahra, et al.

$\triangle$ Corresponding author:

Email Address : reginaazzahra6@gmail.com (Batusangkar, Sumatera Barat, Indonesia)

Received 5 May 2021, Accepted 29 September 2021, Published 04 Oktober 2021 


\section{PENDAHULUAN}

Ariyanti (2016:55-57) dalam bukunya anak itu memiliki potensi untuk dikembangkan. Anak usia dini adalah sekelompok anak dalam proses pertumbuhan dan perkembangan. Tumbuh kembang anak (koordinasi motorik halus dan motorik kasar), kemampuan berpikir, kreativitas, bahasa dan komunikasi sesuai dengan tingkat perkembangan anak. Anak usia dini merupakan sosok yang sedang menjalani tumbuh kembang yang cepat dan mendasar bagi kehidupan berikutnya. Rentang usia pada anak usia dini adalah 0-6 tahun. Menurut John Locke dalam Magta (2013:224) mengatakan bahwa anak seperti kertas putih, baik buruk yang terjadi pada anak dipengaruhi oleh lingkungannya. Sedangkan menurut Stern yang didukung oleh Piaget (dalam Magta, 2013:224) menyatakan anak memiliki mental yang aktif dan rasa ingin tahu untuk membentuk pertumbuhan dan perkembangan melalui proses beradaptasi dengan pengalamannya.

Berdasarkan ketentuan Bab I pasal 1 ayat 14 Undang-undang Nomor 20 Tahun 2003 tentang Sistem Pendidikan Nasional, pendidikan anak usia dini (PAUD) adalah suatu upaya penyuluhan bagi anak sejak lahir sampai dengan usia 6 tahun, dengan pemberian rangsangan pendidikan untuk membantu tumbuh kembang jasmani dan rohani anak agar memliki kesiapan dalam memasuki pendidikan lebih lanjut.

Dalam Kamus Besar Bahasa Indonesia (2007: 802) mendefinisikan ayah dan ibu kandung adalah orang tua; orang tua ialah orang tua yang berakal, cerdas, ahli, dan terhormat. Dalam kehidupan seorang anak, orang tua lebih didefinisikan sebagai ayah dan ibu dan mereka sangat menentukan tumbuh kembang karakter anak.

Menurut ketentuan pedagogi, orang tua adalah kumpulan sosial yang pertama dalam kehidupan anak, wadah bagi anak dalam belajar dan mengungkapkan diri sebagai makhluk sosial tertentu. Dalam perspektif pedagogi, orang tua adalah sosok dalam keluarga yang mempunyai tanggung jawab terbesar untuk mendidik anak-anaknya, yaitu ayah serta ibu.

Menurut Padmonodewo (2013:123) orang tua ialah pendidik awal untuk anak. Setelah anak masuk sekolah, orang tua merupakan mitra kerja utama anak. Bahkan sebagai orang tua, mereka memiliki peran yang berbeda, yaitu sebagai siswa, sebagai pengambil keputusan, dan sebagai tim yang bekerja dengan pendidik. Peran penting orang tua disebut juga dengan keterlibatan orang tua yang diberikan pada anaknya.

Keterlibatan orang tua dapat diartikan ikut sertanya orang tua dalam pendidikan dan pengalaman anaknya. Terlibatnya orang tua di pendidikan anak usia dini akan berdampak baik jika orang tua mengetahui arti, wujud serta maksud dari keterlibatannya tersebut. Partisipasi yang dilakukan oleh orang tua di rumah juga di sekolah adalah berbagai aktivitas yang bertujuan untuk memaksimalkan pertumbuhan dan pendidikan anak di sekolah yang akan membawa manfaat bagi mereka, anak dan juga sekolah.

Pengasuhan anak merupakan sesuatu yang unik dari budaya dan suatu masyarakat, oleh sebab itu pola pengasuhan akan berbeda dari satu masyarakat ke masyarakat lainnya. Sama halnya dengan pembelajaran yang diberikan oleh keluarga yang akan sesuai dengan bentuk yang sesuai dengan hal yang dianut oleh keluarga tersebut.

Salah satu budaya lokal yang melakukan pengasuhan dan pemberian pembelajaran kepada anak ialah budaya Minangkabau. Masyarakat Minangkabau sangat menjunjung tinggi adat istiadat yang ada pada daerahnya yang akan berujung pada nilai ketuhanan yang dikenal dengan "adat basandi syarak, syarak basandi kitabullah". Nilai ketuhanan inilah yang ditanamkan kepada anak sedari dini dengan adanya keterlibatan orang tua dalam menanamkannya.

Terlibatnya orang tua dalam pendidikan anak usia dini sudah seharusnya dilaksanakan dengan baik, tepat dan cepat bagi anak usia dini. Namun, harapan tersebut bertolak belakang dengan kenyataan. Berdasarkan studi pendahuluan yang penulis lakukan pada tanggal 13 Juli 2020, di RA Al-Falah Bina Insan Islami Batusangkar diperoleh permasalahan sebagai berikut: Pertama, orang tua yang rata-rata lebih sibuk dalam pekerjaan mereka tidak sepenuhnya meluangkan waktu untuk dapat terlibat dalam pendidikan anaknya. Kedua, dikarenakan adanya pandemi Covid-19 ini orang tua mengalami penurunan 
dalam ekonomi sehingga orang tua kesulitan dalam melibatkan diri pada pendidikan anaknya. Ketiga, orang tua memang mengantarkan anaknya ke TK atau Paud namun orang tua hanya memikirkan bahwa permasalahan yang dihadapi anak adalah sepenuhnya tanggung jawab guru atau tenaga pendidik di sekolah.

Hawes dan Jasney (dalam (Diadha, 2015:64) mengungkapkan terlibatnya orang tua pada pendidikan anak usia dini tidak hanya sebatas dalam kegiatan anak, namun keterlibatan orang tua pada pendidikan anak usia dini ini juga meliputi bagaimana orang tua melihat tumbuh kembang anak, intensnya komunikasi dengan guru, menentukan bahwa anak menikmati kegiatannya sebagai bentuk dari pembelajaran, membimbing anak untuk mempunyai motivasi belajar yang besar. Kemudian keterlibatan orang tua untuk anak ini juga harus didukung oleh sekolah dengan bentuk sekolah bekerja sama dengan orang tua, dengan hal tersebut maka akan memberikan semangat pada guru dalam proses pembelajaran.

Ada beberapa penelitian sebelumnya yang memperkuat keikutsertaan orang tua dalam pendidikan anak usia dini, yaitu: Pertama, (Yuliasari, Humaira, Fitria, 2018) dengan judul penelitian keterlibatan orang tua dalam program sekolah di Tk Raudhatul Azhar. Dari penelitian yang dilakukan di TK Raudhatul Azhar penulis dapat melihat bahwa dengan terlibatnya orang tua dalam pendidikan anak dapat bermanfaat baik untuk sekolah maupun orang tua. Manfaat terlibatnya orang tua dalam pendidikan anak usia dini dapat dilihat sebagai berikut: (1) program sekolah menjadi lancar, (2) kemampuan anak meningkatkan, (3) orang tua tahu akan perkembagan anak, (4) menjadi wadah untuk bersilaturrahmi dan berdiskusi. Kedua, (Daflora \& Jaya, 2019) dengan penelitian yang berjudul analisis pemahaman orang tua siswa akan keterlibatannya dalam pendidikan anak usia dini. Dalam penelitian tersebut tampak bahwa orang tua paham dengan baik akan terlibatnya mereka pada pendidikan anak usia dini. Orang tua berpendapat dalam pengembangan kemampuan yang dimiliki anak sedari dini itu perlu untuk dilakukan baik oleh orang tua sendiri maupun dengan bekerjasama antara orang tua dengan TK/PAUD.

Ketiga, (Irma et al., 2019) dengan judul penelitian keterlibatan orang tua dalam pendidikan anak usia dini di TK Masyitoh 1 Purworejo. Hasil penelitian menunjukkan realisasi keterlibatan orang tua dalam pendidikan anak di TK Masyitoh 1 Purworejo dilakukan melalui program-program parenting education, informasi tentang pendidikan dan pengembangan, dan dan kesehatan anak, pertunjukan penampilan anak, serta adanya partisipasi pada kegiatan sekolah. Keempat, (Fauziah et al., 2020) dengan penelitian praktik pengasuhan, keterlibatan orang tua di sekolah, konsep diri anak, dan kesiapan sekolah. Subjek yang dilibatkan oleh peneliti terdari dari 55 anak perempuan dan 45 anak laki-laki. Dari hasil penelitian dapat dilihat bahwa keikutsertaan orang tua dalam pendidikan anak dibuktikan dengan usaha yang dilakukan orang tua dengan selalu mengantarkan anak ke sekolah, berkomunikasi dengan guru perihal perkembangan anak, dan berusaha untuk mencarikan sekolah terbaik bagi anak. Kelima, (Kurniati et al., 2020) dengan judul penelitian analisis peran orang tua dalam mendampingi anak di masa pandemi covid-19. Dari hasil penelitian menunjukkan bahwa secara umum peran orang tua muncul adalah sebagai pembimbing, pendidik, penjaga, pengembang dan pengawas. Secara khusus, peran orang yang muncul yaitu: menjaga dan memastikan anak untuk menerapkan hidup bersih dan sehat, mendampingi anak dalam mengerjakan tugas sekolah, menjadi role model bagi anak, menjadi pembimbing dan memotivasi anak, dan membantu anak dalam kegiatan anak yang berbasis pada kebutuhan anak selama pandemi dan BDR.

Tujuan penelitian ini ialah untuk mendeskripsikan keterlibatan orang tua di Minangkabau dalam pendidikan anak usia dini pada masa pandemi covid-19. Terlibatnya orang tua di pendidikan anak usia dini akan berdampak baik jika orang tua mengetahui arti, wujud serta maksud dari keterlibatannya tersebut. Partisipasi yang dilakukan oleh orang tua di rumah juga di sekolah adalah berbagai aktivitas yang bertujuan untuk memaksimalkan pertumbuhan dan pendidikan anak di sekolah yang akan membawa manfaat bagi mereka, anak dan juga sekolah. 
Penelitian ini menarik karena dalam kondisi pandemi covid-19 akan dapat memunculkan kembali keterlibatan orang tua, baik dalam pendidikan maupun dalam setiap kegiatan anaknya. Terlibatnya orang tua dalam pendidikan anak menjadi sangat penting karena mengharuskan orang tua untuk ikut serta dalam pendidikan anak agar pada masa pandemi covid-19 ini anak masih mendapatkan pendidikan berupa kegiatan maupun aktivitas yang dilakukan bersama orang tua di rumah.

\section{METODOLOGI}

Penelitian yang digunakan dalam penelitian ini adalah penelitian kualitatif dengan memakai metode deskriptif kualitatif. Metode deskriptif kualitatif merupakan metode penelitian yang mendeskripsikan keterlibatan orang tua di Minangkabau dalam pendidikan anak usia dini pada masa pandemi covid-19. Berikut ini merupakan alur penelitian kualitatif. (Sugiyono, 2013)

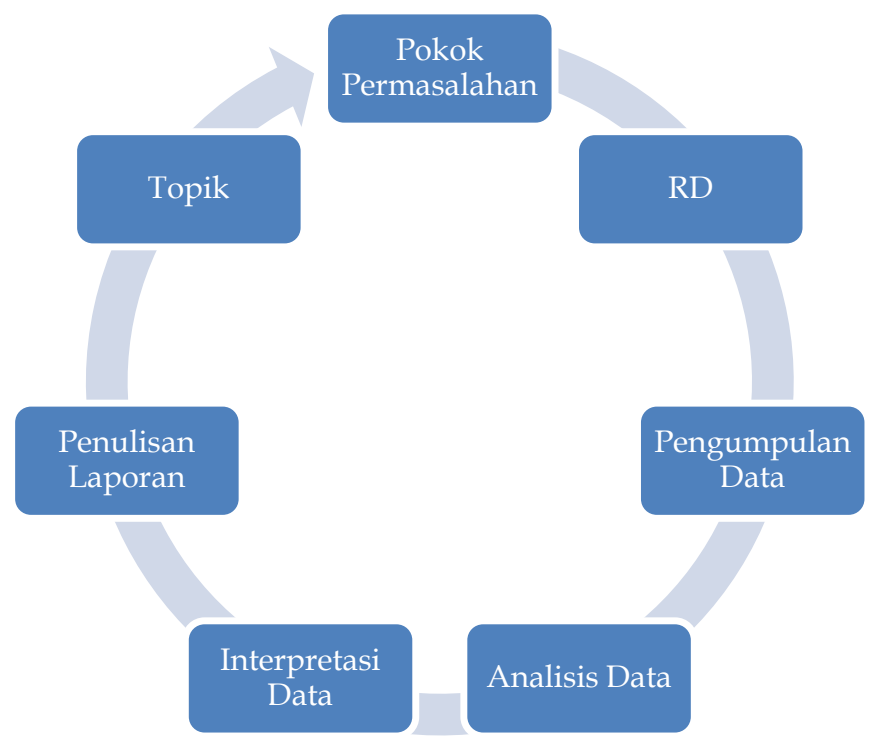

Gambar 1. Alur penelitian kualitatif

Subjek penelitian terdiri dari orang tua, guru sebagai pengajar anak, dan kepala sekolah sebagai pimpinan sekolah RA. Al-Falah Bina Insan Islami Batusangkar. Subjek dari penelitian ini berjumlah 7 orang terdiri dari 5 orang tua yang menyekolahkan anaknya di RA. Al-Falah Bina Insan Islami Batusangkar, 1 orang guru sebagai pengajar anak, dan 1 orang kepala sekolah sebagai pimpinan sekolah RA. Al-Falah Bina Insan Islami Batusangkar yang juga berinteraksi dengan orang tua. Jumlah informan pada penelitian ini yaitu 7 orang. Pengambilan informan dengan jumlah 7 orang karena meminimalisir tersebarnya pandemi covid-19 yang mengaharuskan agar tetap menjaga jarak serta setiap kegiatan agar dilakukan di rumah saja, kemudian pemilihan informan diambil dari 5 orang tua juga 2 orang dari pihak sekolah yang terdiri dari kepala sekolah dan guru yang mengajar anak di RA. Al-Falah Bina Insan Islami Batusangkar karena menurut peneliti sudah cukup data yang didapatkan dari informan tersebut. Lokasi penelitian ini dilakukan di RA. Al-Falah Bina Insan Islami Batusangkar. Teknik pengumpulan data menggunakan teknik observasi langsung ke lapangan, wawancara dan dokumentasi. Analisis data yang dilaksanakan dalam penelitian ini memiliki dua metode analisis, yaitu analisis saat meningkatkan keabsahan data dan analisis ketika interpretasi data secara keseluruhan. Sebagai gambaran alur analisis data yang dilakukan sebagai berikut: (Sugiyono, 2013)

Analisis data yang dilaksanakan dalam penelitian ini memiliki dua metode analisis, yaitu analisis saat meningkatkan keabsahan data dan analisis ketika interpretasi data secara keseluruhan. Tahapan analisis data juga tidak menutup kemungkinan adanya reduksi data. Reduksi data adalah pemulihan data yang direkam ulang dalam bentuk deskripsi dan laporan 
sistem yang terperinci. Ini dilaksanakan guna meninjau semua catatan yang didapatkan dari observasi, wawancara, serta dokumentasi, kemudian merangkum, setelah itu memilih hal-hal yang utama dan penting. Setelah dilakukan reduksi data kemudian dilakukanlah penyajian data yang dimungkinkan untuk pengambilan kesimpulan atau verifikasi. Untuk memastikan keabsahan data adalah dengan teknik triangulasi. Dalam penjaminan keabsahan data pada penelitian ini memakai triangulasi teknik dilaksanakan melalui cara pengecekan data pada sumber yang sama dengan teknik yang berbeda. Pada penelitian ini triangulasi teknik dilakukan dalam bentuk observasi dan wawancara. Kemudian triangulasi sumber dilaksanakan melalui pengecekan ulang data yang diperoleh dengan berbagai sumber, yang diperoleh melalui orang tua, guru yang mengajar dan kepala sekolah sebagai pimpinan sekolah yang juga berinteraksi dengan orang tua. (Sugiyono, 2013)

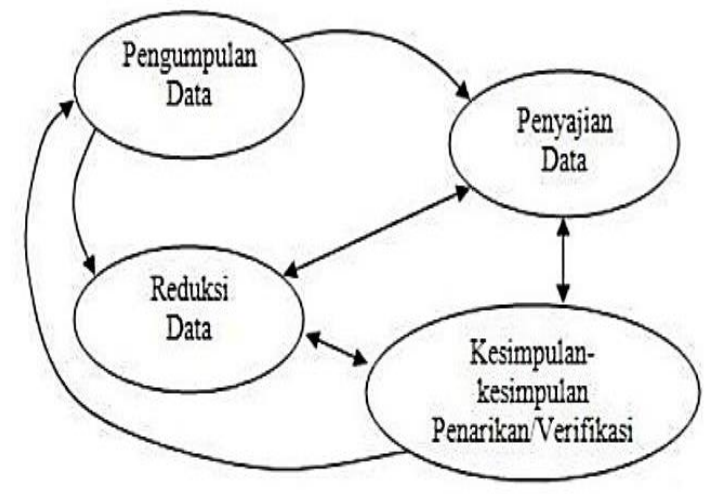

Gambar 2. Alur analisis data

\section{HASIL DAN PEMBAHASAN}

Dalam kajian yang dilakukan oleh Naim (1984) menghimpun data pekerjaan orang Minangkabau yang sudah disurvey dan menemukan rata-rata pekerjaan mereka ialah berdagang. Berikut ini merupakan penyajian data hasil observasi yang diambil dari 5 orang informan yaitu orang tua yang menyekolahkan anaknya di RA. Al-Falah Bina Insan Islami Batusangkar.

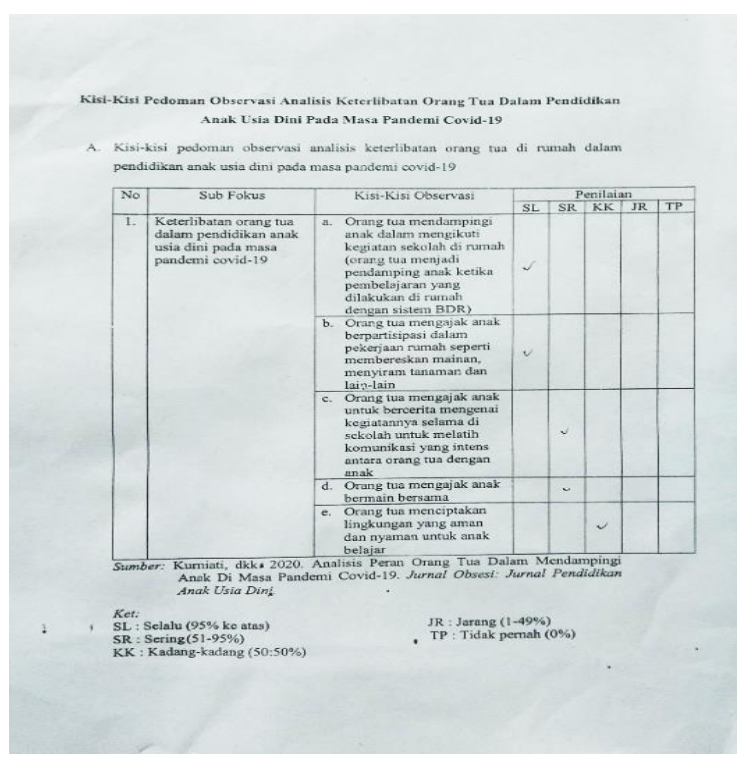

Gambar 3. Hasil observasi dari Ibu D

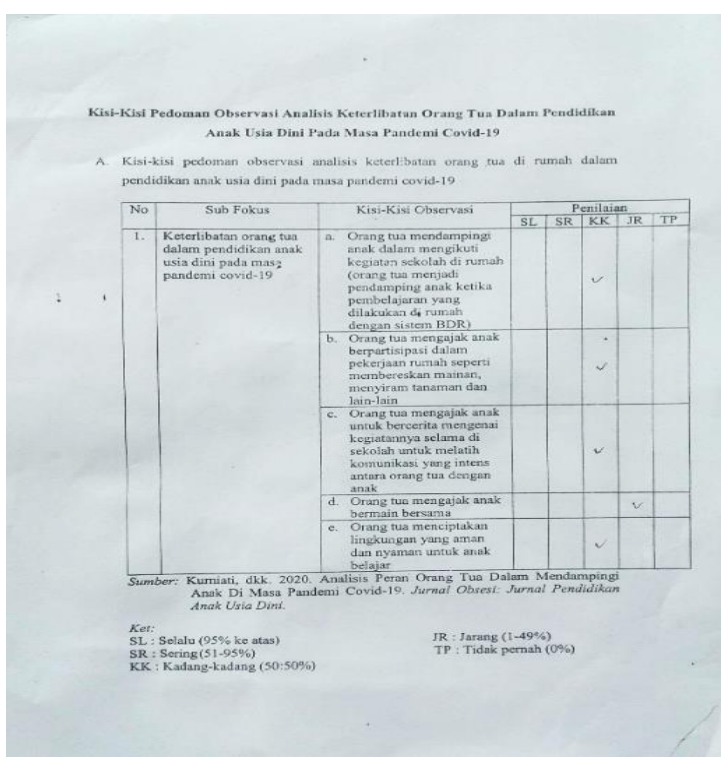

Gambar 4. Hasil observasi dari Ibu R 


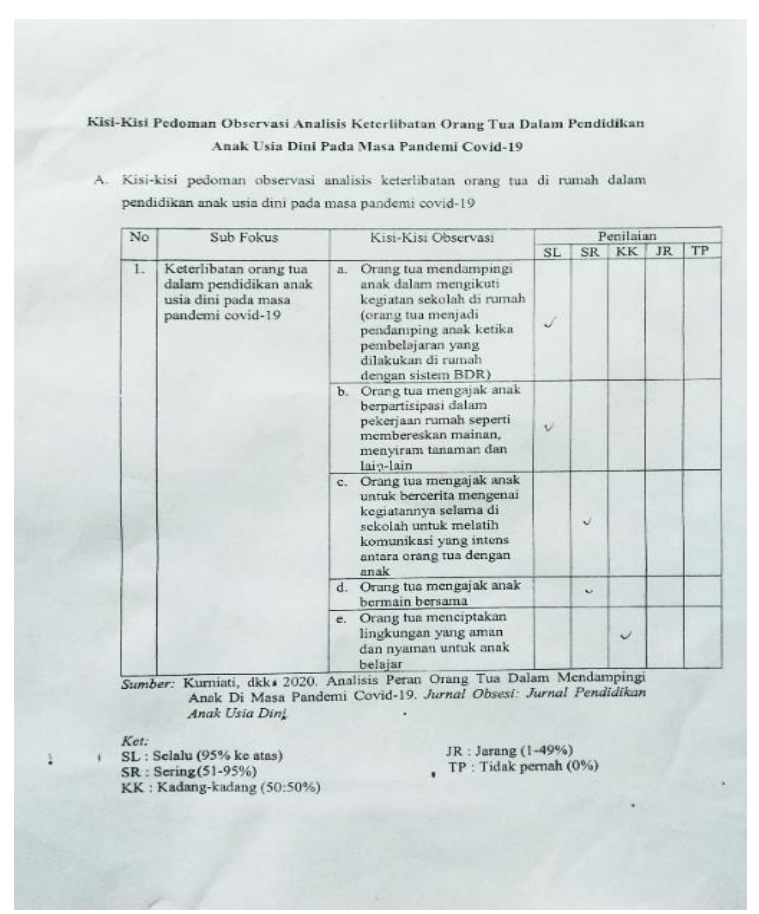

Gambar 5. Hasil observasi dari Ibu L

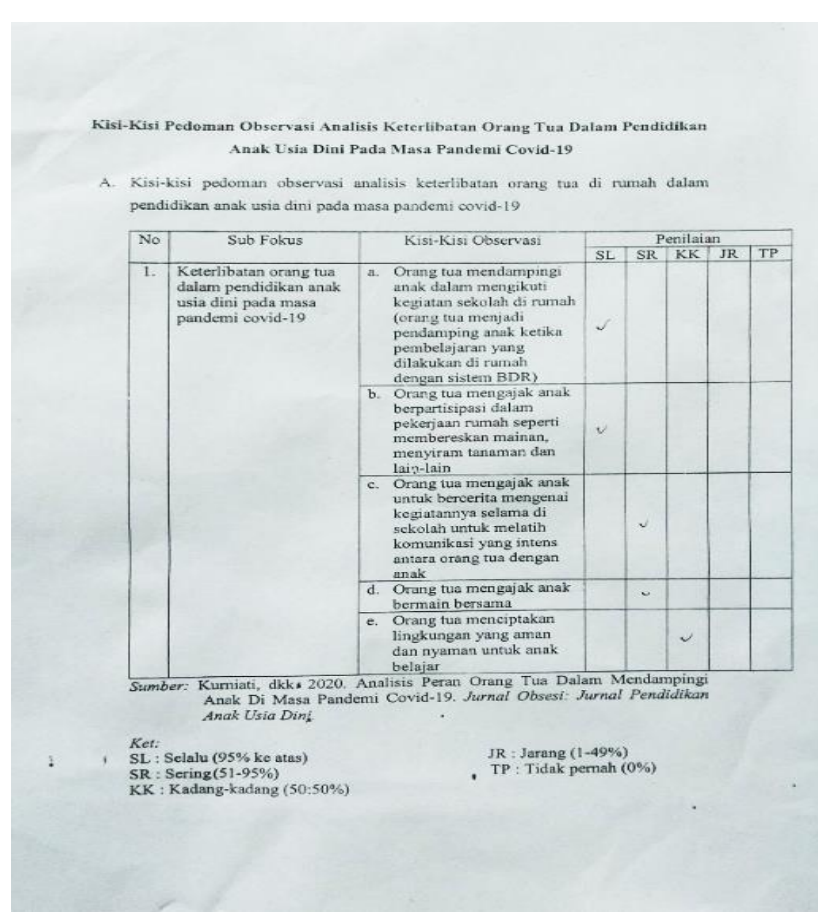

Gambar 6. Hasil observasi dari Ibu W

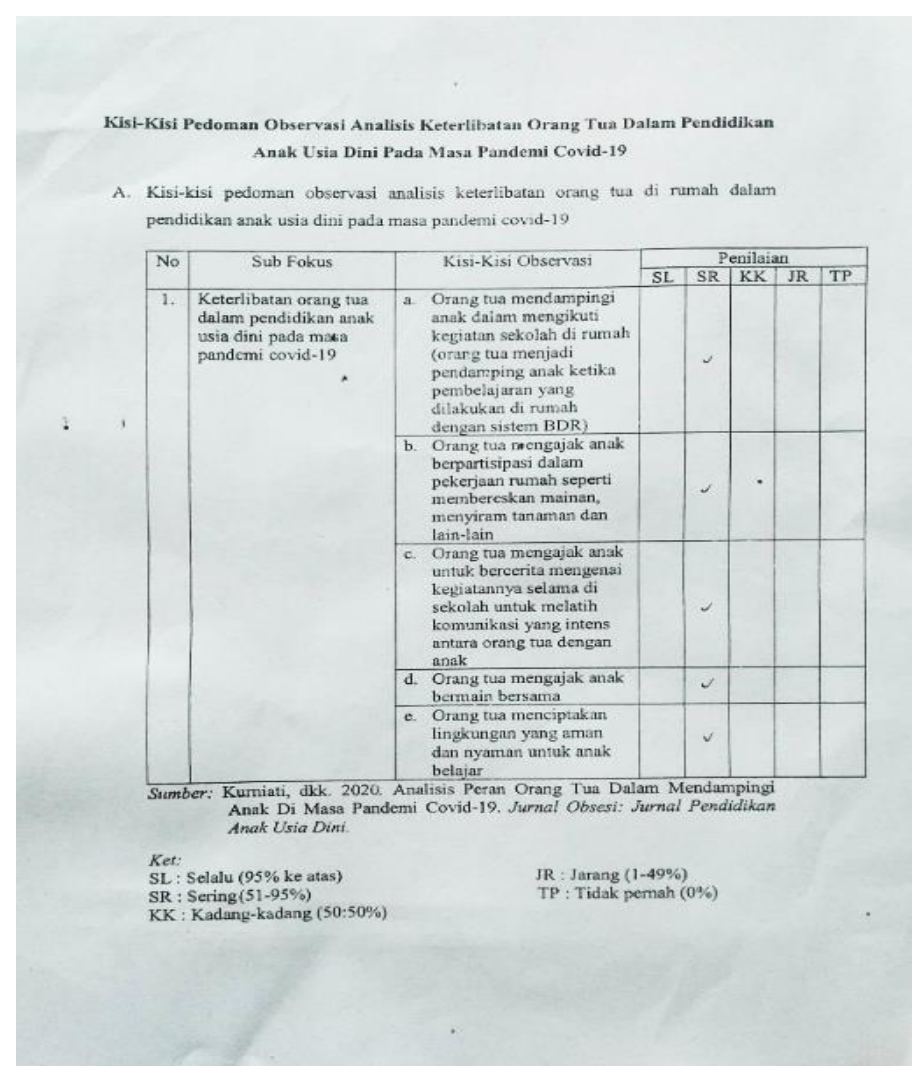

\section{Gambar 7. Hasil observasi dari Ibu N}

Berdasarkan hasil observasi yang dilakukan dengan melihat langsung ke rumah orang tua mengenai keterlibatannya dalam pendidikan anak usia dini pada masa pandemi covid-19, maka di dapatkanlah data berupa ada 3 orang tua setiap hari, ada 1 orang tua sering, dan ada 1 orang tua kadang-kadang ikut serta dalam kegiatan anak. Dalam kegiatan pekerjaan membersihkan rumah ada 3 orang tua setiap hari, ada 1 orang tua sering, dan ada 1 orang tua 
kadang-kadang mengajak anak berpartisipasi dalam kegiatan pekerjaan membersihkan rumah. Pada kegiatan mengajak anak saling bercerita kembali mengenai kegiatannya ada 3 orang tua yang setiap hari, dan ada 2 orang tua yang kadang-kadang mengajak anaknya bercerita kembali mengenai kegiatan yang dilakukan. Selanjutnya untuk mengajak anak bermain bersama terlibat bahwa ada 4 orang tua yang setiap hari, dan ada 1 orang tua yang jarang mengajak anak untuk bermain bersamanya. Kemudian dalam menciptakan rumah yang nyaman dan aman untuk anak belajar ada 3 orang tua yang sudah sering, dan ada 2 orang tua yang kadang-kadang menciptakan lingkungan yang nyaman dan aman untuk anak belajar.

\section{Keterlibatan Orang Tua}

Menurut semantik Gomes (2017:23) mengatakan keterlibatan adalah partisipasi seseorang pada keadaan tertentu. Artinya bahwa seseorang tersebut memainkan peran tertentu dalam situasi tertentu. Situasi yang dimaksud ialah siatuasi yang membangkitkan pandangan dan sikap masyarakat terhadap peristiwa tersebut. Secara psikologis, partisipasi diartikan sebagai proses memposisikan diri pada sesuatu atau mengarahkan diri kepada suatu hal.

Berdasarkan arti semantik dan psikologis, keterlibatan adalah partisipasi seseorang dalam bentuk pemenuhan peran dan tanggung jawab tertentu dalam suatu peristiwa. Peran dan tanggung jawab ini dilakukan secara bersama guna mencapai tujuan yang diinginkan. Keterlibatan orang tua sangat berperan penting dalam pendidikan anak. Pentingnya keikutsertaan orang tua dalam pendidikan anak usia dini dapat dilihat dari partisipasi orang tua dalam mengasuh anaknya di TK. Hal ini akan mengeratkan hubungan orang tua dan anak, orang tua yang ikut serta dalam kegiatan anak sehari-hari di sekolah akan bisa menerapkan ilmu barunya saat mendidik anak di rumah.

Untuk melihat keterlibatan orang tua dalam pendidikan anak usia dini pada masa pandemi covid-19 peneliti melakukan wawancara dengan 7 informan yaitu 5 orang orang tua dari anak-anak yang bersekolah di RA Al-Falah Bina Insan Islami Batusangkar dan 2 informan dari pihak sekolah yaitu guru serta kepala sekolah RA Al-Falah Bina Insan Islami Batusangkar. Tabel 1 adalah hasil wawancara 1 yang peneliti lakukan.

Terlibatnya orang tua dalam pendidikan anak akan memberi efek baik jika orang tua juga guru mengerti akan arti, wujud serta maksud dari keterlibatannya tersebut. Arti partisipasi orang tua dalam pendidikan anak juga telah dijelaskan oleh beberapa ahli dalam definisi yang berbeda. Jeynes (dalam Hornby, 2011:1) mendefinisikan keikutsertaan orang tua sebagai “...proses dan pengalaman keikutsertaan orang tua dalam pendidikan anak mereka”. Penjelasan ini menunjukkan bahwa keikutsertaan orang tua yang dimaksud oleh Jeynes mengacu pada hadirnya orang tua di sekolah, termasuk dalam proses pembelajaran yang diikuti anak, sampai pada akhirnya orang tua juga dapat melalui apa yang dilalui anak dalam proses pendidikan yang dilaluinya.

Gomes (2017:23) dalam bukunya keterlibatan orang tua adalah partisipasi individu dalam keadaan tertentu. Ini berarti bahwa individu tersebut memainkan peran tertentu dalam situasi tertentu. White dan Coleman juga mengemukakan pandangan lain tentang definisi terlibatnya orang tua dalam pendidikan anak dalam Diadha (2015:63-64), mereka mengartikan terlibatnya orang tua sebagai partisipasi dalam berbagai aktivitas yang dilaksanakan orang tua juga guru di sekolah dan di rumah sebagai upaya bersama guna menunjang pendidikan anak.

Dalam sebuah tulisan Bibi dalam Sari dan Luthfia (2019:25) menyebutkan dalam sebuah tulisannya yaitu "parent involvement is a process of helping parent use their abilities of henefit them selves, their children and their early childhood program" artinya adanya partisipasi orang tua adalah sebuah proses untuk mendukung orang tua memakai segala kemampuannya untuk mengambil untung bagi dirinya, anak-anak dan program yang dilaksanakan. 


\section{Tabel 1. Hasil Wawancara 1}

\begin{tabular}{|c|c|}
\hline Informan & Hasil Wawancara Dengan Informan \\
\hline D & $\begin{array}{l}\text { Oo kegiatan selama covid ini seperti BDR, oo setiap tugas yang dikasih guru kita harus oo } \\
\text { mendampingi anak ini untuk melaksanakan tugasnya, membuat prakaryanya, } \\
\text { membimbingnya dalam mengaji dan hafalan-hafalan ayat dan sebagainya. }\end{array}$ \\
\hline $\mathbf{R}$ & $\begin{array}{l}\text { Menulis, misalnya tulis angka 1-10, mengajari tangannya tu lurus ndak, mengenalkan A-Z aa } \\
\text { gitu, dan berhitung. (Menulis, misalnya tulis angka 1-10, mengajari tangannya lurus } \\
\text { atau tidak, mengenalkan huruf A-Z, dan berhitung.) }\end{array}$ \\
\hline $\mathbf{L}$ & $\begin{array}{l}\text { Mmm sholat, mmm belajar membaca, juga membantunya dalam kegiatan BDR. Mama } \\
\text { dampingi belajarnya, mama ikut membantu dalam menyampaikan tugas atau prakarya yang } \\
\text { disuruh sama ustadzahnya dari sekolah lewat chat grup di wa kan. }\end{array}$ \\
\hline $\mathbf{W}$ & $\begin{array}{l}\text { Oo mengajari Azizah, belajar, mengaji al-qur'an, oo pembuatan pembelajaran BDR, murajaah } \\
\text { hafalannya, sholat dhuha. Umi ikut membantu mengulang lagi bacaannya, terus begitulah zah. }\end{array}$ \\
\hline $\mathbf{N}$ & $\begin{array}{l}\text { Kegiatan o yo manunjuakan aa yang disuruah dek ustadzahnyo. Beko pas lah siap nyo baraja } \\
\text { tu beko nyo mangaji lai, siap tu ado lo main beko gai. Patang pas BDR di rumah inyo mambuek } \\
\text { tugas tu beko kalu ndak bisa ama mambuek an tu beko inyo malanjuik an lai. (Kegiatannya } \\
\text { ya menunjukan apa yang disuruh oleh ustadzah (guru). Nanti ketika sudah selesai } \\
\text { belajar dia mengaji, setelah itu ada pula waktu untuk main bersamanya. Kemaren } \\
\text { ketika BDR di rumah dia yang bikin tugas terus nanti kalau ada yang tidak bisa mama } \\
\text { yang buatkan dulu habis itu baru dia yang melanjutkan lagi.) }\end{array}$ \\
\hline Guru & $\begin{array}{l}\text { Ee kemaren saat semester } 1 \text { keterlibatannya dalam tahfidz, ee hafalan hadist, sholat dhuha terus } \\
\text { sholat } 5 \text { waktu, terus bacaan sholatnya, dzikirnya doanya, terus waktu pembelajarannya sesuai } \\
\text { dengan tema, sub tema dengan video. Nanti ustadzahnya mengirim video ke orang tua, nanti } \\
\text { orang tua yang mengajarkan kepada anaknya. Fasilitasnya dari orang tua yang dikembangkan } \\
\text { oleh orang tua itupun mengajarkannya dengan menggunakan media loose part yah sesuai } \\
\text { dengan benda-benda yang ada di lingkungan sekitar rumah. }\end{array}$ \\
\hline Kepsek & $\begin{array}{l}\text { Pada masa pandemi covid-19 kita ada daring ada juga luring. Nah yang ketika daring anak- } \\
\text { anak kan belajar di rumah bersama orang tua, anak di dampingi oleh orang tua. Kegiatan } \\
\text { pembelajaran itu disesuaikan dengan kondisi lingkungan di sekitar rumah, contohnya dalam } \\
\text { penggunaan media, alat dan bahan, gunakanlah benda-benda yang ada di sekitar rumah dengan } \\
\text { arahan bimbingan dari orang tua di rumah. Untuk kegiatan sendiri konsepnya dari sekolah } \\
\text { pengembangannya dari orang tua di rumah. }\end{array}$ \\
\hline
\end{tabular}

\section{Pengasuhan Budaya Minangkabau}

Pengasuhan anak merupakan hal yang sangat unik dari adanya budaya dari suatu masyarakat, oleh sebab itu pengasuhan serta keikutsertaan setiap orang tua akan berbeda dari satu masyarakat ke masyarakat lainnya. Sama halnya dengan keterlibatan satu keluarga dalam pendidikan dan kegiatan anak mereka akan sangat berbeda yang sesuai dengan apa yang dianut dan tradisi tersendiri dari keluarga tersebut. (We \& Fauziah, 2020)

Salah satu budaya yang berbeda tersebut ialah budaya lokal Minangkabau. Pembelajaran yang diberikan kepada anak oleh masyarakat Minangkabau ialah berdasarkan dengan adat istiadat yang amat sangat dijunjung tinggi yang akan berujung pada ketuhanan yang biasa dikenal dengan "adat basandi syarak, syarak basandi kitabullah". Hal inilah yang diberikan oleh orang tua di Minangkabau dalam pendidikan anak mereka sedari dini.

\section{Manfaat Keterlibatan Orang Tua dalam PAUD}

Untuk melihat manfaat keterlibatan orang tua dalam pendidikan anak usia dini pada masa pandemi covid-19 ini maka peneliti melakukan wawancara dengan 7 informan yaitu 5 orang orang tua dari anak-anak yang bersekolah di RA Al-Falah Bina Insan Islami Batusangkar dan 2 informan dari pihak sekolah yaitu guru serta kepala sekolah RA Al-Falah Bina Insan Islami Batusangkar. Tabel 2 adalah hasil wawancara 2 yang peneliti lakukan.

Berdasarkan hasil wawancara 2 dengan 7 orang informan maka manfaat keterlibatan orang tua dalam pendidikan anak usia dini pada masa pandemi covid-19 memberikan manfaat untuk anak, sekolah dan orang tua itu sendiri dibuktikan dengan perkembangan anak yang meningkat membuat orang tua merasa senang serta adanya kepuasan yang dirasakan oleh 
DOI: $10.31004 /$ obsesi.v6i3.1796

pihak sekolah karena segala bentuk program sekolah yang berupa kegiatan bagi anak dapat dijalankan dengan baik berkat ikut serta dan bersinerginya orang tua dalam menjalankan kegiatan tersebut dalam sistem BDR (belajar dari rumah).

Menurut Gomes (2017:25) orang tua yang berpartisipasi dalam pendidikan anak usia dini akan bermanfaat untuk anak, sekolah dan orang tua itu sendiri. Untuk anak, terlibatnya orang tua dalam pendidikan akan membantu akademiknya, adanya peningkatan kemandirian juga kehadiran anak di sekolah, kemudian anak sadar akan hidup yang bersih dan sehat, serta anak akan berperilaku dengan baik.

Dengan melibatkan orang tua pada program sekolah, maka akan memberi manfaat untuk sekolah yaitu, akan memperbaiki suasana sekolah, dapat meningkatkan sekolah yang berkualitas, dan masalah kedisiplinan akan terkurangi. Ini akan terjadi jika hubungan antara orang tua dan pihak sekolah dapat dibangun dengan baik. Hubungan yang terbangun baik antara orang tua dan guru akan berpengaruh positif sekolah.

Sedangkan untuk orang tua partisipasi di sekolah akan memudahkan orang tua dalam menyamakan bentuk aktivitas anak di rumah dengan kegiatannya di sekolah, orang tua dapat memberi dukungan untuk peningkatan tumbuh kembang anak, dapat menambah kepuasan terhadap guru dan mempererat hubungan dengan anak.

\section{Tabel 2 Hasil Wawancara 2}

\begin{tabular}{|c|c|}
\hline Informan & Hasil Wawancara Dengan Informan \\
\hline D & $\begin{array}{l}\text { Manfaatnya dengan sendirinya bunda juga bisa belajar dari kegiatan yang dilakukan di } \\
\text { sekolah bunda juga bisa mengikuti pembelajaran yang diberikan, oo banyak sedikitnya bunda } \\
\text { juga bisa oo lebih mengahafal lagi ayat-ayat yang ada di al-qur'an. Perilaku yang ditunjukkan } \\
\text { anak juga sangat baik, dia mau mengikuti proses pembelajaran oo belajar BDRnya dengan } \\
\text { baik, dia tahu dengan tanggung jawabnya. }\end{array}$ \\
\hline $\mathbf{R}$ & $\begin{array}{l}\text { Kalau anak tu dapek dek nyo kan awak sanang lo hati wak kan, nyo bisa mambuek wak puas } \\
\text { tu a sanang. Tu, anak wak lai namuah nyo ikut serta nyo maapoan tugasnya. Tapi misalnyo } \\
\text { ndak suko nyo itu yang agak payah wak dek nyo, mancari mood anak wak do payah. (Kalau } \\
\text { anak itu bisa jadi kan hati saya senang juga, dia bisa lah membuat saya puas gitu } \\
\text { senang. Juga, anak saya mau ikut serta dia mengerjakan tugasnya. Tapi misalnya dia } \\
\text { nggak suka itu yang agak susah saya mencari kemauannya.) }\end{array}$ \\
\hline $\mathbf{L}$ & $\begin{array}{l}\text { Oo lebih tau dengan perkembangan Gio, apa saja yang dibutuhkan sama Gio. Kemudian } \\
\text { Alhamdulillah anak saya juga baik perilakunya, dia banyak mengetahui mana yang baik dan } \\
\text { mana yang buruk. Udah bisa mengeja dan membaca iqra'. }\end{array}$ \\
\hline $\mathbf{W}$ & $\begin{array}{l}\text { Dia, hehe yang dirasakan ya senang karena Azizah sudah banyak kepandaiannya. Dan juga } \\
\text { kalau untuk bikin tugas dia mau mengerjakan tugasnya, kadang-kadang anak-anaklah } \\
\text { namanya yah zah yah kadang-kadang dia bosan, kadamg malas. }\end{array}$ \\
\hline $\mathbf{N}$ & $\begin{array}{l}\text { Lah banyak yang dapek dek inyo tu a, lah banyak pandai nyo, lah banyak bisa nyo. Tu Gebi ko } \\
\text { kalau samo ama lai namuahnyo baraja, kadang inyo mintak bana "ma baraja lu". Lai } \\
\text { patuahnyo. (Sudah banyak yang di dapat oleh dia, sudah banyak kepandaiannya, } \\
\text { sudah banyak yang dia bisa. Lalu, Gebi ini kalau sama mama mau dia belajar, } \\
\text { kadang-kadang dia yang minta "ma belajar dulu". Dia patuhlah.) }\end{array}$ \\
\hline Guru & $\begin{array}{l}\text { Manfaat untuk sekolah sangat baik dengan adanya orang tua ikut serta dalam pendidikan } \\
\text { anaknya dibuktikan dengan adanya komunikasi yang biasanya orang tua cuma nanya gini } \\
\text { "zah besok sekolah?" hanya itu. Nah kalau sekarang dengan belajar yang di rumah BDR maka } \\
\text { komunikasi dengan orang tua lebih banyak karena akan tampak perhatian orang tua pada anak } \\
\text { lebih banyak dengan adanya covid-19. Mm lalu ada kepuasannya tu gini anak itu tidak hanya } \\
\text { dapat dari sekolah saja, tapi ada juga tambahan di rumah bahkan mengulang. Jadi dengan } \\
\text { banyaknya pengulangan itu dapat melebihi target yang sekolah ingin capai. }\end{array}$ \\
\hline Kepsek & $\begin{array}{l}\text { Untuk sekolah Alhamdulillah oo lebih baik lagi, karena program-program kita juga sudah } \\
\text { berjalan sesuai dengan yang direncanakan dan ketercapaiannya luar biasa. Kemudian kami } \\
\text { juga puas sekali, senang sekali karena memang hasilnya itu nyata gitu kan. Tampak jelas dari } \\
\text { perkembangan anak. }\end{array}$ \\
\hline
\end{tabular}




\section{Faktor Pendorong Keterlibatan Orang Tua dalam PAUD}

Untuk mengetahui faktor pendorong keterlibatan orang tua dalam pendidikan anak usia dini pada masa pandemi covid-19 maka peneliti melakukan wawancara dengan 7 informan yaitu 5 orang orang tua dari anak-anak yang bersekolah di RA Al-Falah Bina Insan Islami Batusangkar dan 2 informan dari pihak sekolah yaitu guru serta kepala sekolah RA AlFalah Bina Insan Islami Batusangkar. Tabel 3 adalah hasil wawancara 3 yang peneliti lakukan.

Orang tua yang terlibat dalam pendidikan anak usia dini didorong dengan keinginan serta semangat dari orang tua juga adanya pemberian motivasi dan pemahaman akan perlunya partisipasi orang tua dalam pendidikan anak usia dini. Menurut Diadha (2015:67) menyatakan setiap aktivitas yang dilakukan orang tua saat terlibat dalam pendidikan anak usia dini akan didorong oleh berbagai faktor. Keterlibatan orang tua dalam pendidikan anak usia dini dapat dilihat dengan keyakinan orang tua tentang keterlibatan mereka dalam pendidikan anak usia dini dan bagaimana persepsi orang tua mengenai pendidikan anak usia dini. Dengan keyakinan orang tua dan persepsi mengenai pentingnya keikutsertaan orang tua dalam pendidikan anak usia dini yang tinggi maka hal tersebut akan mendukung orang tua untuk ikut terlibat dalam pendidikan anaknya.

\section{Tabel 3. Hasil Wawancara 3}

\begin{tabular}{cl}
\hline Informan & \multicolumn{1}{c}{ Hasil Wawancara Dengan Informan } \\
\hline $\mathbf{D}$ & $\begin{array}{l}\text { Bunda ingin memberikan yang terbaik untuk anak, ingin pendidikan yang terbaik, hal yang } \\
\text { baik dalam pencapaian sesuatu dan nilai yang memuaskan untuk nantinya. }\end{array}$ \\
Karna keinginannyo tu ado, tu samangek lo wak manyakolahkannyo. (Karena keinginannya \\
itu ada, karena itu semangat juga saya menyekolahkannya.) \\
L \\
Mama mau ikut terlibat tu karena Gio nih banyak bisa gitu kayak membaca iqra', mengeja dan \\
lainnya. \\
Soal o kalau samo ama lai patuahnyo. Dek itu ama yang harus maaja inyo. (Soal nya kalau \\
sama mama dia patuh. Karena itu mama yang harus mengajar dia.) \\
Lah banyak yang dapek dek inyo tu a, lah banyak pandai nyo, lah banyak bisa nyo. Tu Gebi ko \\
kalau samo ama lai namuahnyo baraja, kadang inyo mintak bana "ma baraja lu". Lai \\
patuahnyo. (Sudah banyak yang di dapat oleh dia, sudah banyak kepandaiannya, \\
sudah banyak yang dia bisa. Lalu, Gebi ini kalau sama mama mau dia belajar, kadang- \\
kadang dia yang minta "ma belajar dulu". Dia patuhlah.) \\
Ee yang pertama itu ada pesan untuk semester 1 emang diberikan dulu pengertian kepada orang \\
tua betapa pentingnya pendidikan anak sejak usia dini. Betapa pentingnya pendidikan, betapa \\
pentingnya anak itu dikembangkan 6 aspek perkembangannya, betapa pentingnya anak itu \\
dikenali bagaimana perkembangannya gitu karena pada usia segitu adalah usia golden age kan. \\
Jadi, memang harus diberikan pengertian. \\
Yang pertama tentu diberi dulu pemahaman kepada orang tua hakikat anak usia dini itu apa \\
gitu kan, karena seperti yang kita ketahui banyak orang tua yang masih menganggap bahwa \\
anak TKatau Paud ke sekolah itu belajar, duduk manis itu saja kan, tapi yang sebenarnya tidak. \\
Jadi, pemahaman itu dulu yang dijelaskan kepada para orang tua.
\end{tabular}

\section{Faktor Penghambat Keterlibatan Orang Tua dalam PAUD}

Untuk mengetahui faktor penghambat keterlibatan orang tua dalam pendidikan anak usia dini pada masa pandemi covid-19 maka peneliti melakukan wawancara dengan 7 informan yaitu 5 orang orang tua dari anak-anak yang bersekolah di RA Al-Falah Bina Insan Islami Batusangkar dan 2 informan dari pihak sekolah yaitu guru serta kepala sekolah RA AlFalah Bina Insan Islami Batusangkar. Tabel 4 adalah hasil wawancara 4 yang peneliti lakukan. Berdasarkan hasil wawancara diatas maka dapat disimpulkan bahwa disamping orang tua terdorong untuk melibatkan diri dalam pendidikan anak usia dini juga terdapat beberapa hal yang menghambat orang tua ikut serta dalam pendidikan anak usia dini, yaitu: orang tua lebih sibuk dalam bekerja sehingga tidak dapat meluangkan waktu sepenuhnya untuk anak, dan sebagian dari orang tua mengalami penurunan penghasilan akibat terjadinya pandemi covid19 yang membuat orang tua tidak dapat ikut serta dalam kegiatan anak. Menurut Gomes 
(2017:26) ada beberapa hal yang membuat orang tua tidak banyak melibatkan diri pada pendidikan anak usia dini ialah kendala yang berasal dari individu orang tua sendiri diantaranya sibuknya orang tua dalam pekerjaan, dan kondisi kehidupan orang tua, serta adanya faktor penghambat dari luar yaitu minimnya pemahaman guru akan perlunya orang tua terlibat dalam pendidikan anak, kemampuan anak belajar, perilaku anak serta bertambahnya usia anak dengan sendirinya akan membuat perkembangan dalam tahapan belajar anak.

Hornby \& Lafaele (dalam Gomes, 2017:27) mengungkapkan keterlibatan orang tua menurun disertai dengan usia anak yang bertambah, potensi belajar anak, dan tingkah laku baik anak. Dengan bertambahnya usia anak, maka potensi dan kemandiriannya dalam belajar akan semakin meningkat dan berkembang pesat. Faktor penghambat orang tua saat ikut serta dalam pendidikan maupun kegiatan anaknya disebabkan oleh kesibukan orang tua dalam pekerjaan, dengan kesibukan ini maka orang tua tidak dapat sepenuhnya meluangkan waktu untuk anaknya. Kemudian orang tua juga terhambat untuk melibatkan diri dalam pendidikan anak karena tidak mampunya orang tua menggunakan bahasa yang sesuai dan benar saat mengajak anak belajar di rumah. Penggunaan bahasa yang tepat dan benar bagi anak usia dini dalam belajar sangat perlu karena dalam masa usia dini inilah anak akan memulai proses pembelajaran awal.

\section{Tabel 4 Hasil Wawancara 4}

\begin{tabular}{cl}
\hline Informan & \multicolumn{1}{c}{ Hasil Wawancara Dengan Informan } \\
\hline D & Hambatannya mungkin karena ada pekerjaan rumah tangga sehari-hari yang membuat belajar \\
anak kurang lancar, kadang ditunda-tunda dulu. Heheh.. & Hambatannyo mungkin dek hp android wak rusak, tu ndak bisa wak ikuik BDR do. Tu rasaki \\
yang agak kurang kini untuk manyokolahkannyo. (Hambatannya mungkin karena hp \\
android saya rusak, jadi nggak bisa ikut BDR. Terus rezeki yang agak kurang sekarang \\
untuk menyekolahkannya.) \\
Mmp mungkin kalau ada pekerjaan yang mendesak terus digantikan oleh papanya dulu nantik \\
jika papanya juga ga bisa barulah keluarga yang ada di rumah zah \\
Mungkin meluangkan waktu sepenuhnya untuk Azizah, karena umi punya 3 anak yang masih \\
kecil-kecil. Terus kalau di sekolah lebih fokus belajar sambil bermain, masuk jam 07.15 sampai \\
jam 11.00, kalau di rumah banyak godaannya zah seperti Azizah ini agak rewel dan banyak \\
teman yang datang bermain zah. \\
Kalau di rumah anak ko payah disuruah baraja zah, soal o anak-anak baru ka sanang baraja di \\
sakolah lah baranti lo. (Kalau di rumah anak ini susah untuk belajar zah, soalnya anak- \\
anak baru akan senang belajar di sekolah terus sudah disuruh pula berhenti.) \\
Aa yang pertama yang sering ustadzah terima laporannya hambatannya itu paling orang tua \\
bertanya "zah bagaimana yah cara mengajarkannya zah?". Tapi 80\% orang tua paling yang \\
menghambat itu karena orang tua belum paham betul cara mengajarkan atau cara \\
menyampaikan bahasa yang baik kepada anak. \\
Kalau sejauh ini mungkin hanya masalah waktu, karena rata-rata wali murid itu pekerja ya atau \\
PNS dan orang kantoran. Yang pergi pagi pulang sore yang memang waktu untuk memantau \\
kegiatan anak itu tidak banyak.
\end{tabular}

\section{SIMPULAN}

Keterlibatan orang tua di Minangkabau dalam pendidikan anak usia dini pada masa pandemi covid-19 terbilang masih ada namun memang tidak sepenuhnya dilakukan oleh orang tua karena sibuk bekerja. Keterlibatan tersebut bermanfaat meningkatkan perkembangan anak. Bagi orang tua dapat menambah semangat untuk meningkatkan pendidikan anak, sedangkan bagi sekolah dapat memberikan kepuasan program sekolah yang berjalan. Orang tua terdorong untuk ikut serta dalam peningkatan aspek perkembangan anaknya. Penurunan penghasilan akibat terjadinya pandemi covid-19 membuat sebagian dari orang tua terhambat untuk ikut serta dalam kegiatan anak. 


\section{UCAPAN TERIMA KASIH}

Peneliti mengucapkan terimakasih kepada semua pihak yang berperan penting dalam penelitian ini, terutama kepada kedua orang tua, pembimbing (Dr. Wahidah Fitriani, S. Psi., M.A) dan penguji (Dra. Desmita, M.Si dan Dr. Jhoni Warmansyah, M. Pd) yang telah memberikan semangat, nasehat serta masukan yang membangun sampai penelitian ini selesai. Tak lupa pula peneliti ucapkan terimakasih untuk para informan yang telah meluangkan waktu serta berpartisipasi dalam penelitian ini.

\section{DAFTAR PUSTAKA}

Ahmad, R. (2014). Pengantar Pendidikan: Asas Dan Filsafat Pendidikan. Ar-Ruzz Media: Yogyakarta.

Amini, M. (2015). Profil Keterlibatan Orang Tua Dalam Pendidikan Anak Usia Tk. JIV-Jurnal Ilmiah Visi, 10(1), 9-20. https:// doi.org/10.21009/JIV.1001.2

Ariyanti, T. (2016). Pentingnya Pendidikan Anak Usia Dini Bagi Tumbuh Kembang Anak. Jurnal Dinamika Pendidikan Dasar, 8(1), 50-58.

Daflora, R., \& Jaya, R. P. (2019). Analisis Pemahaman Orang Tua Siswa Akan Keterlibatannya Dalam PAUD. PAUDIA : Jurnal Penelitian Dalam Bidang Pendidikan Anak Usia Dini, 8(2), 10-19. https://doi.org/10.26877/paudia.v8i2.4606

Daulay, N. (2014). Pola asuh orangtua dalam perspektif psikologi dan Islam. Jurnal Darul Ilmi, 02(02), 76-91.

Diadha, R. (2015). Keterlibatan Orang Tua Dalam Pendidikan Anak Usia Dini Di Taman Kanak-Kanak. Edusentris, 2(1), 61. https://doi.org/10.17509/edusentris.v2i1.161

Emzir. (2011). Analisis Data: Metodologi Penelitian Kualitatif. Rajawali Pers: Jakarta.

Fauziah, H., Hastuti, D., \& Yuliati, L. N. (2020). Parenting Practice, Parental Involvement in School, Child's Self Concept and School Readiness. Jurnal Ilmu Keluarga Dan Konsumen, 13(1), 61-74. https:// doi.org/10.24156/jikk.2020.13.1.61

Gomes, F. De. (2017). Parental Guidance Service : Kiat Meningkatkan. Jurnal Pendidikan Dan Kebudayaan Missio, 9(10), 21-34.

Handoko, W. D., Fauziah, P., \& Dimyati, D. (2021). Gaya Pengasuhan Anak Usia Dini pada Suku Dayak Dusun Laek Desa Bengkilu. Jurnal Obsesi : Jurnal Pendidikan Anak Usia Dini, 6(2), 728-737. https://doi.org/10.31004/obsesi.v6i2.1021

Indrijati, H. (2016). Psikologi Perkembangan Dan Pendidikan Anak Usia Dini: Jakarta.

Irma, C. N., Nisa, K., \& Sururiyah, S. K. (2019). Keterlibatan Orang Tua dalam Pendidikan Anak Usia Dini di TK Masyithoh 1 Purworejo. Jurnal Obsesi : Jurnal Pendidikan Anak Usia Dini, 3(1), 214. https://doi.org/10.31004/obsesi.v3i1.152

Kurniati, E., Nur Alfaeni, D. K., \& Andriani, F. (2020). Analisis Peran Orang Tua dalam Mendampingi Anak di Masa Pandemi Covid-19. Jurnal Obsesi : Jurnal Pendidikan Anak Usia Dini, 5(1), 241. https:// doi.org/10.31004/obsesi.v5i1.541

Mauanah, S. (2016). Parenting Education Sebagai Pendidikan Keluarga. Paradigma, 04(2), 110. https://media.neliti.com/media/publications/252153-parenting-educationsebagai-pendidikan-k-a2f303db.pdf

Meta-analisis, S. (2016). Keterlibatan Orangtua dalam Pendidikan dan Komitmen Siswa terhadap Sekolah: Studi Meta-analisis. Buletin Psikologi, 21(1), 31. https:/ / doi.org/10.22146/bpsi.9844

Mubarok, A. A. S. A. Al. (2018). Parenting dan Pelibatan Orang Tua pada Lembaga Pendidikan Anak Usia Dini. Al-Hikmah: Indonesian Journal of Early Childhood Islamic Education,2(1),30.http://journal.staialhikmahtuban.ac.id/index.php/ijecie/article/vi $\underline{\mathrm{ew} / 15}$

Oktavianingsih, E. (2019). Pengembangan Program Pelibatan Orangtua dalam Penyelenggaraan Pendidikan Anak Usia Dini. Journal of Early Childhood Care and Education, 1(2), 1. https:// doi.org/10.26555/jecce.v1i2.231

Padmono, S. (2013). Pendidikan Anak Prasekolah. PT Rineka Cipta: Jakarta. 
DOI: 10.31004/obsesi.v6i3.1796

Pidarta, M. (2013). Landasan Pendidikan. PT Rineka Cipta: Jakarta.

Pramawaty, N., Hartati, E., Program, M., Keperawatan, S. I., \& Kedokteran, F. (2012). Hubungan Pola Asuh Orang Tua Dengan Konsep Diri Anak Usia Sekolah (10-12 Tahun). Jurnal Nursing Studies, 1, 87-92. http://ejournals1.undip.ac.id/index.php/jnursing

Retnaningtya, M. S., \& Paramitha, P. P. (2015). Keterlibatan orang tua dalam pendidikan anak di tk anak ceria. Jurnal Psikologi Pendidikan Dan Perkembangan, 4(1), 9-17. https://doi.org/10.21009/JIV.1001.2

Santikko, I., \& Mariyati, L. I. (2019). Bentuk keterlibatan orang tua pada anak tk yang berprestasi melukis. Jurnal Psikologi Poseidon, 2(1), 58-67. https://journal.ugm.ac.id/ipsi/article/view/17801/15824

Sukiman. (2017). Orang Tua Hebat. In Kementraian Pendidikan dan Kebudayaan (Vol. 98, Issue 25). $\quad$ http://118.98.227.114/glnsite/wpcontent/uploads/2017/09/Juknis_PAUD.pdf

Sugiyanto. (2016). Menjadi Hebat Untuk Keluarga dengan Anak Usia Dini.

Sugiyono. (2013). Metode Penelitian Keantitatif, Kualitati, R\&D. Bandung: Alfabeta.

We, A. Y., \& Fauziah, P. Y. (2020). Tradisi Kearifan Lokal Minangkabau "Manjujai" untuk Stimulasi Perkembangan Anak Usia Dini. Jurnal Obsesi : Jurnal Pendidikan Anak Usia Dini, 5(2), 1339-1351. https:// doi.org/10.31004/obsesi.v5i2.660

Yuliasari, Humaira, Fitria, N. dan Z. (2018). Journal of Early Childhood Care \& Education. Journal of Early Childhood Care \& Education JECCE, 1(2), 28-40. https://doi.org/10.26555/jecce.v1i2.254 